\title{
Leaderless Resistance: Development, Countering and Research of Insurgent Concept
}

\section{Odpor bez vůdce: vývoj, potlačování a výzkum povstaleckého konceptu}

\section{Miroslav Mareš}

Abstract: The paper deals with an insurgent strategic concept "leaderless resistance". It was elaborated by US intelligence officer Colonel Ulius Louis Amoss. It is used by various insurgent actors and it is researched within the context of insurgency and counterinsurgency and interconnected issues (extremism, terrorism etc). The author of this contribution deals with the development tendencies and with the strengths and weaknesses of this strategy (including the derived concepts as "leaderless Jihad" etc.). Its adaptation in the era of modern political and hybrid warfare is explained. Challenges for successful countering from the point of view of security architecture (intelligence and law enforcement agencies, army, non-.state actors) are discussed.

Abstrakt: Článek se zabývá povstaleckým strategickým konceptem „odporu bez vůdce". Byl vytvořen americkým zpravodajským důstojníkem plukovníkem Uliusem Louisem Amossem. Je užíán rưznými aktéry a je zkoumán v kontextu povstalectví a proti-povstalectví a souvisejících problémů (extremismus, terorismus apod.). Autor tohoto příspěvku se zabývá vývojovými tendencemi a silnými a slabými aspekty této strategie (včetně odvozených konceptů, jako je „džihád bez vůdce“ apod.). Je vysvětlena jeho adaptace na moderní politickou a hybridní válku. Diskutovány jsou výzvy pro úspěšné potírání z hlediska bezpečnostní architektury (zpravodajství a agentury vymáhající právo, armáda, nestátní aktéři).

Keywords: Resistance; Counter-insurgency; Extremism; Terrorism; Intelligence.

Klíčová slova: Odboj; proti-povstalectví; extremismus; terorismus; zpravodajství. 


\section{INTRODUCTION}

Historical and contemporary insurgencies and their countering pose a significant challenge to military forces, law enforcement agencies and intelligence services. Insurgent strategies and tactics are also objects of expert discussions and academic research. Theory and practice can be in a close interconnection, as the development of the concept "leaderless resistance" shows. A short essay written originally by US intelligence officer Ulius Louis Amoss in the early $1950 \mathrm{~s}$ was later able to affect several important insurgent thinkers from various extremist scenes and it has a strong impact also in contemporary world. Underdeveloped seems to be research of its recent impact on the military sphere.

The goals of this article are to explain the origins, spread and contemporary use of "leaderless resistance", to analyze its specific interconnection with the military sphere (including its overlap with modern political and hybrid warfare) and to discuss challenges of countering this phenomenon. With respect to these goals, the research questions are: 1) how "leaderless resistance" affected insurgent and terrorist strategies, 2) how can "leaderless resistance" be interconnected with the military sphere and 3) how this strategy can be successfully eliminated. A strategic analysis within the context of research of insurgency and terrorism as well as approaches of intelligence studies will be used ${ }^{1}$. East Central European perspective is emphasized in the article, because the impact of "leaderless resistance" was not systematically researched in this area² (despite the fact that the origins of the concept have strong ties to East Central Europe - see below).

\section{ANALYTICAL FRAMEWORK: A NETWORK PERSPECTIVE, (NON)HIERARCHY AND CELLS}

The concept of "leaderless resistance" is based on a free structure of actors involved. Due to this fact, the best approach how to understand its position within the spectrum

1 GOMPER, David C., Paul K. DAVIS, Stuart E. JOHNSON a Duncan LONG. Analysis of Strategy and Strategies of Analysis. RAND Corporation, 2008. ISBN 13: 9780833045034.

2 Some specific issues related to extreme right "lone wolves" were discussed in MAREŠ, Miroslav a Richard STOJAR. Extreme right perpetrators. FREDHOLM, Michael. Understanding Lone Actor Terrorism.: Past experience, future outlook, and response strategies. London: Routledge, 2016, s. 66-86. ISBN 9781138309142 . The diploma thesis written by Pavel Drlík offers an interesting case study of the "National Resistance". DRLík, Pavel. Prípadová studie aktéra "Netwar". Brno, 2009. Dostupné také z: https://is.muni. cz/th/ocvin/Pripadova_studie_aktera_netwar.pdf. Bakalářská práce. Masarykova univerzita. Vedoucí práce Martin Bastl. 
of insurgent strategies (including terrorist strategies ${ }^{3}$ ) should be based on a structural analysis of subversive entities. Such approach offers a network analysis, elaborated by Richard Matthew and George Shambaugh. They divided terrorist structures into two main categories: 1) the traditional hierarchical model with a commander and subordinated units 2) modern "netwar" model consisting of free non-hierarchical network of involved units 4 . The hierarchical model can include more commando-levels (a pyramidal model) or the leaders can coordinate cells and these cells do not have contacts among them (centralized coordinated model). Within the "network" structure we can distinguish between interconnected linear network of cells (they coordinate directly and immediately their activities) and a diffused model (cells without direct contacts among them, they are coordinated only by common goals, not by direct communication and coordination). In a very simplified way the foundations of these models are outlined in the following graphics.

\section{Basic models of insurgent structures}

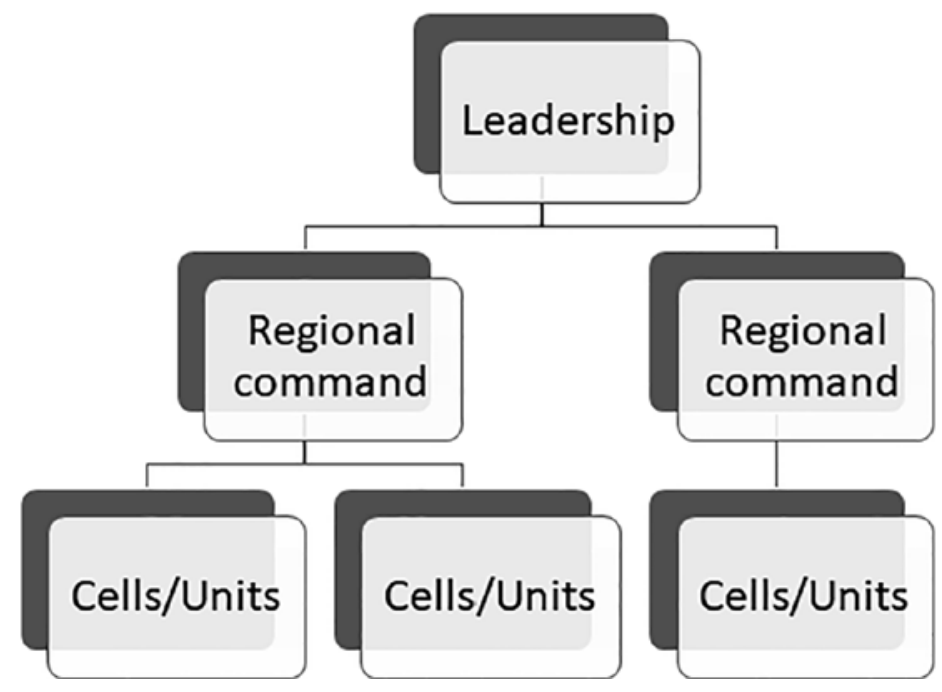

Scheme 1: Pyramidal hierarchical model

3 Due to the fact that contemporary conceptualizations of insurgencies and terrorism are in many cases closely interconnected, in this article subversive terrorism will be subsumed under a broader spectrum of insurgent strategies. This approach is typical of Israeli expert Ariel Merari. See MERARI, Ariel. Terrorism as a strategy of insurgency. Terrorism and Political Violence. 1993, 5(4), 213-251. DOI: 10.1080/09546559308427227. ISSN 0954-6553. Dostupné také z: http://www.tandfonline.com/doi/ abs/10.1080/09546559308427227

4 MATTHEW, Richard a George SHAMBAUGH. The Limits of Terrorism: A Network Perspective1. International Studies Review. 2005, 7(4), 617-627. DOI: 10.1111/j.1468-2486.2005.00536.x. ISSN 1521-9488. Dostupné také z: https://academic.oup.com/isr/article-lookup/doi/10.1111/j.1468-2486.2005.00536.x. 


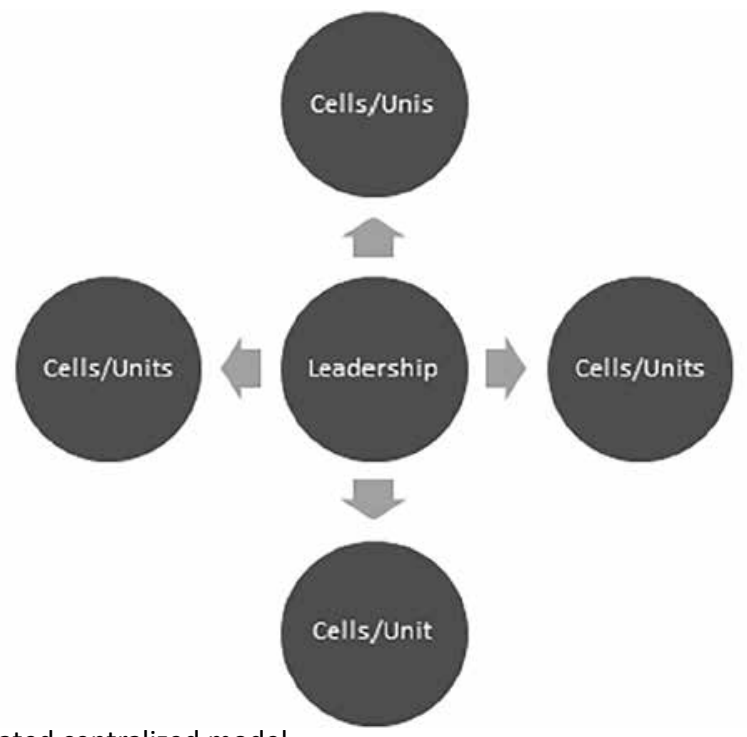

Scheme 2: Coordinated centralized model

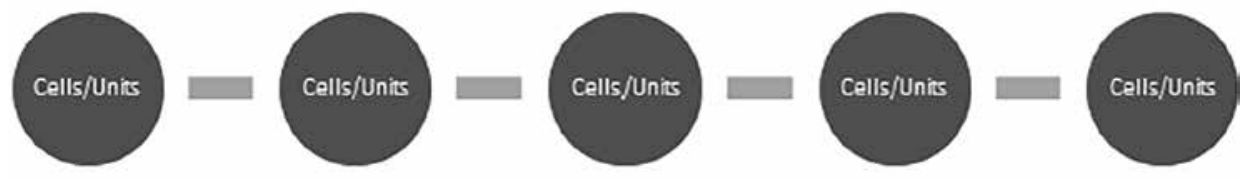

Scheme 3: Linear model

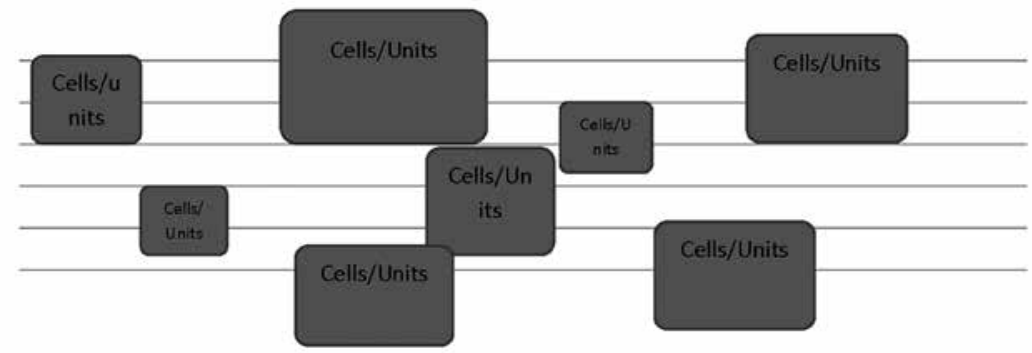

Scheme 4: Diffused model 
In the diffused model some units/cells can play much a more important role than the others and their importance can step by step create informal and later formal leadership in an insurgent movement. It is important to emphasize that the dynamics of networks plays an important role in their analysis as well as in their countering. According to Matthew and Shambaugh: "if network-based terrorist groups are successful in creating a more hierarchical structure, the increased organization and higher levels of coordination will likely generate new preferences and new vulnerabilities that make these hierarchical terrorist networks easier to target and neutralize ${ }^{\prime 5}$

Each insurgent movement faces several dilemmas. Ethan Frisch identified the following ones:

1. Action versus secrecy (requirement to carry out attacks on the one hand and to be caught on the other hand);

2. Growth versus control (a growing number of members, controlled areas and actions lead to loss of efficient control over the insurgent movement);

3. Recruitment versus retention (how to force the recruited members to fulfil their commitments and to keep them in the insurgent organization);

4. Success versus longevity (insurgent organizations should achieve at least shortterm goals and to survive to achieve long-term goals);

5. Resources versus constituencies (insurgents groups need support and sources from the population and if they use direct violence against people, they cause "constituent alienation") 6 . Free network of cells can be a rational choice in the first phase of insurgencies, later it can transform into more deeply structured and/or hierarchical forms. In such cases the concept of proto-insurgency can be useful for an analysis. David Byman defines proto-insurgency as „, a small, violent group that seeks to gain the size necessary to more effectively achieve its goals and use tools such as political mobilization and guerrilla warfare as well as terrorism" ". If the insurgent movement maintains the free cell or the linear model in a long-term perspective, it can be subsumed under the concept of the 4th generation of warfare ${ }^{8}$ and also under new concepts of warfare (as will be more deeply discussed later in the "military" chapter of this article).

5 MATTHEW, Richard a George SHAMBAUGH. 2005, 626.

6 FRISCH, Ethan. Insurgencies are Organizations Too: Organizational Structure and the Effectiveness of Insurgent Strategy. Peace \& Conflict Review. 2011, 6(1), 17-41. ISSN 1659-3995. Dostupné také z: http:// www.review.upeace.org/images/pcr6. 1. pdf

7 BYMAN, Daniel. Understanding Proto-Insurgencies. Santa Monica: RAND Corporation, 2007. ISBN 9780833041364. Dostupné také z: https://www.rand.org/content/dam/rand/pubs/occasional_papers/2007/ RAND_OP178.pdf

8 Fourth generation of warfare is characterized by the fact that "in response to the overwhelming capability of the modern conventional military forces, weaker opponents began resorting alternative ways of waging wars, as insurgency, "terrorism" and other forms of "asymmetric" conflict." PERLA, Peter P., Albert A. NOFI a Michael C. MARKOWICZ. Wargaming Fourth Generation Warfare (U). [online]. Alexandria: CNA Corporation, 2006 [cit. 2020-06-28]. Dostupné z: https://www.cna.org/CNA_files/PDF/D0014752.a2.pdf 


\section{ORIGINS OF THE CONCEPT: FAILURE OF WESTERN SECRET OPERATIONS IN THE COMMUNIST BLOC}

"Leaderless resistance" is recently presented as an example of the diffused model used by non-state actors, however, it was created with more sophisticated - "statelinked" - goals and with the potential to change into different forms of insurgency. Its origins must be understood within the context of the beginning of the Cold War (and its possible outbreak into the "hot" Third World War"). The author of the original concept was Ulius Louis Amoss9. He published his essay called "Leaderless Resistance. New Tactics for an Old War " in 1953 for US intelligence community for the first time. After his death it was reprinted for broader public on 17 April $1962^{10}$.

The main message of the paper is unsatisfaction with the Western approach towards anti-communist resistance movements in Eastern Europe and with many failures of secret agents from exile organizations that cooperated with Western intelligence services. He stated the West was losing the Cold War, because: "The enemy has adopted new tactics, tactics that make the classic underground system obsolete, tactics that doom great secret organizations because they can no longer remain secret."11

The scope of primarily Amoss's criticism was relatively narrow. It aimed at the fact that communist agents penetrated into exile political organizations. This fact caused the above mentioned disclosure of whole insurgent networks in the countries of the Communist Bloc. He also evaluated overestimation of the role of money negatively, which was supplied by Western special services to the hands of resistance organizations and these were willing to act only due to this financial support. Lack of leaders characterized resistance in the communist countries and the exile organizations were not able to generate "new Titos" (in the sense of strong insurgent commanders after the model Josip Broz Tito during the Second World war) ${ }^{12}$.

Polish political émigré and their controversial links caused Amoss' biggest concern. He emphasized the destruction of the Polish underground organization "Association Freedom and Independence" (Zrzeszenie Wolność i Niezawisłość - WiN"). As Amoss wrote, its

9 Colonel Ulius Louis Amoss was a US intelligence officer of Greek origin. He was born in 1895. During the Second World War he joined the Office of Strategic Services (OSS") and led its office in Kairo (which was responsible for operations in Northern Africa and Southern Europe). Since 1947 he worked for the Central Intelligence Agency (CIA) and in 1948 he established the allegedly commercial International Services of Information (INFORM), however, it was a CIA cover organisation. He died in 1961. SIMKIN, John. Ulius Louis Amoss. In: Spartacus Educational [online]. N.: Spartacus Educational, 1997 [cit. 2020-06-28]. Dostupné z: https://spartacus-educational.com/JFKamossU.htm

10 AMOSS, Ulius Louis. Leaderless Resistance. New Tactics for an Old War. Inform. 1962, N.(6205), 1-4. (archive of the Wisconsin Historical Society).

11 AMOSS, Ulius Louis. 1962, 1.

12 AMOSS, Ulius Louis. 1962, 1-3. 
leader was uncovered and forced to cooperate with the Polish secret police ${ }^{13}$. Another case was related to parachutists trained at an American intelligence school in Western Germany, who were arrested after communist agents in exile organizations informed their commanders in Warsaw ${ }^{\mathbf{1 4}}$. Trials with Western agents in Poland in 1952-1953 initiated Amoss' reasoning to change the previous approach of US intelligence towards anti-communist resistance in Eastern Europe.

He struggled for segregation of political action (exile government, exile and underground political parties etc.) from intelligence and subversive activity. "Political émigré organizations must never be entrusted with tasks of a military intelligence or subversive nature. Subversive activity must be entrusted only to elite groups, small in size, strictly isolated from one another."15

\section{3 "LEADERLESS RESISTANCE" 1. 0. : SPONTANEOUS FREELY ORGANIZED ANTI-COMMUNIST MOVEMENT WITH WESTERN SUPPORT}

American intelligence should construct its own intelligence network, independent on émigré political institutions. Political emigrants should not be involved in training of intelligence and subversive activities. An exposed (even partially) underground organization, whether American or émigré, must be considered as lost ${ }^{16}$. Amoss also stated: "Individuals who proved successful in underground work under the Germans are not to be considered automatically qualified for work under Soviet occupation. Current psychological, moral and technical factors are vastly different, and so are the loyalties" ${ }^{17}$.

The above mentioned ideas are rooted in intelligence work with own agents. Amoss' main contribution to the theory of insurgency is presented in the last part of his paper.

13 In fact, the WiN was penetrated by agents of the Polish communist secret service called Department of Security (Urząd bezpieczeństwa - UB). They were able to take over control of the leading structure of the WiN. In 1948-1952, the Polish UB played with the CIA a spy game which caused elimination of hundreds anti-communist activists. Polish secret service used the name „Operacja Cezary" for designation of this game. FRAZIK, Wojciech. Operacja "Cezary". Prowokacyjna v komenda WiN. Biuletyn Instytutu Pamięci Narodowej. 2008, 8(1-2 (84-85), 167-170. ISSN 1641-9561.

14 AMOSS, Ulius Louis. 1962, 1-2.

15 AMOSS, Ulius Louis. 1962, 2.

16 AMOSS, Ulius Louis. 1962, 2.

17 AMOSS, Ulius Louis. 1962, 2. 
He labelled ${ }^{18}$ the concept of large underground systems "with its cells everywhere and its couriers swarming from center to center" 19 as passed. As a "sweeping the Soviet orbit" he declared "leaderless resistance", as a spontaneous movement without traditional political representation. This movement should be supported by Western intelligence services.

The core of Amoss' message is in the following sentences: "In the event of war, obviously the West would like the satellite armies to "come to over". This can be achieved only if we are able to create among the rank and file of these armies the proper climate and a genuine desire to do so. No organization is capable of accomplishing this thing. No one's orders would be obeyed. But the rank and file would come over if their morale was properly influenced. For this we do not need "leaders"; we need leading ideas. These ideas would produce leaders. The masses would produce them and the ideas would be their inspiration" 20 .

If we analyze these words, we can see the author's struggle to support a spontaneous movement which follows common ideas and these ideas are able to mobilize to various acts of resistance. The role of US intelligence is to offer popular ideas to oppressed people and to support various parts of the freely organized resistance movement. Real activities can generate new leaders who can take control over broader parts of the movement. With these new leaders Western intelligence should cooperate. "Leaderless resistance" can be also only the starting phase of the resistance movement which can receive new leaders. If the new leaders are uncovered, thanks to the spontaneity and diffusion of the movement, they can be substituted. Amoss predicted: "It could be the time when Bolshevism would pull in its lines, sullenly giving up one country after another - and with no danger of general war"21.

We can see that the concept elaborated by Amoss (he labelled it as "tactics") includes foreign state support through intelligence service to a spontaneous movement, which is not linked to emigrant structures, it is originally non-hierarchically organized and which tries to achieve common popular goals. This movement can change its substance and it will generate new leaders. Interaction of governmental intelligence activities and a leaderless resistant movement in foreign countries are typical of Amoss' original concept.

18 Despite the fact that Amoss did not quote any authors or works linked to this traditional system, might to be that his criticism reacts to the publication written by Ferdinand Otto Miksche. The Czechoslovak emigrant was inspired by the WW II experience and he proposed hierarchical structures with specialized branches as an optimal architecture of an underground movement in his book, which was first published in 1947 (it was re-edited several times and became popular at the turn of the $1940 \mathrm{~s} / 1950 \mathrm{~s}$ ). MIKSCHE, Ferdinand Otto. Secret Forces.: The Technique of Underground Movements. 2. London: Faber and Faber Limited, 1951. ISBN N., p. 113.

19 AMOSS, Ulius Louis. 1962, 3.

20 AMOSS, Ulius Louis. 1962, 3.

21 AMOSS, Ulius Louis. 1962, 4. 


\section{REBIRTH OF “LEADERLESS RESISTANCE” AND ITS SPREAD}

In the era of the publication of the original version of Amoss' paper, it had only a limited impact. According to US expert Chip Berlet, it was propagated in leaflets airdropped over Cuba in 1961, which were prepared by anti-Castro Cuban exile activists with ties to the CIA. Establishing of "phantom cells" (Celulas Fantasmas) was demanded22. "Leaderless resistance" was allegedly discussed also as a model of insurgency in the case of the communist occupation of the United States of America ${ }^{23}$. The white supremacist scene was later responsible for the "2. 0. version" of "leaderless resistance" and for its spread. In 1983, Louis Beam ${ }^{24}$ published in the internal newsletter of the Ku Klux Klan a paper called "Leaderless Resistance", in which he presented and developed Amoss' ideas, adapted for the purposes of white supremacist movement ${ }^{25}$. Beam discussed this concept within the US far right-wing militant scene ${ }^{\mathbf{2 6}}$ and in 1992 his paper was revised and reprinted in the far-right journal "The Seditionist"27. This version was broadly widespread, firs in the United States and later world-wide. It strongly influenced the racist and neo-Nazi scene in many countries.

Beam proposed, similarly as Amoss, establishing of a non-pyramidal resistance movement which will be able to resist against infiltration of enemie's secret agents. In contrast to Amoss, the enemy was not the communist rule, but, federal institutions of the United States of America. The white supremacist scene should be able to generate common

22 BERLET, Chip. Leaderless Resistance Publishing History. Chip Berlet's Blogsite: Research for Progress [online]. http://www.researchforprogress.us/topic/: Chip Berlet, 2017 [cit. 2020-06-28]. Dostupné z: http://www. researchforprogress.us/topic/39014/leaderless-resistance-publishing-history/

23 MCALLISTER, Bradley a Alex P. SCHMID. Theories of Terrorism. SCHMID, Alex P. Routledge Handbook of Terrorism Research. London: Routledge, 2011, s. 201-271. ISBN 9780415411578.

24 Louis Beam was born in 1946. He served as a machine-gunner on helicopter in Vietnam and he was awarded the Distinguished Flying Cross. After return to the USA he started to be active in the militant white racist scene, among others in the Ku Klux Klan and in the organization Aryan Nations. He published his own journal The Seditionist. He is considered an important person in the intellectual and strategic background of the white supremacist scene in the $1980 \mathrm{~s}$ and $1990 \mathrm{~s}$. SOUTHERN POVERTY LAW CENTRE. Louis Beam. Southern Poverty Law Centre [online]. Montgomery: Southern Poverty Law Centre, 2020 [cit. 2020-06-28]. Dostupné z: https://www.splcenter.org/fighting-hate/extremist-files/individual/louis-beam

25 BEAM, Louis. Leaderless Resistance. Inter Klan Newsletter \& Survival Alert. 1983, N.(N.), 12-13. ISSN N. Dostupné také z: https://simson.net/ref/leaderless/1983.inter-klan_newsletter.pdf Beam was active in the Ku Klux Klan, however, he had broader ambitions to mobilize masses of white supremacists. Due to this fact he published a paper about non-hierarchical strategy in the journal published by a strong hierarchical pyramidal organization. Later he left the KKK and also the KKK split into various factions. According to Kathleen Blee and Mehr Latif, a number of local Klans moved more underground and they cooperated with racist skinheads and neo-Nazis. BLEE, Kathleen a Mehr LATIF. Ku Klux Klan. Vigilantism against blacks, immigrants and other minorities. BJØRGO, Tore a Miroslav MAREŠ. Vigilantism against Migrants and Minorities. London: Routledge, 2019, s. 31-42. ISBN 9781138493926.

26 Leader of the organisation White Aryan Resistance (W.A.R.) Tom Metzger was an important partner in these discussions

27 BEAM, Louis. Leaderless Resistance. The Seditionist. 1992, N(12), 1-4. Dostupné také z: http://www. louisbeam.com/leaderless.htm 
ideas and propaganda for phantom cells of the resistance movement. It means that some "strategic circles" of the white supremacist scene have to play a similar role as the US intelligence in the original concept from the $1950 \mathrm{~s}$.

Beam stated: "Members of phantom cells or individuals will tend to react to objective events in the same way through usual tactics of resistance. Organs of information distribution such as newspapers, leaflets, computers, etc., which are widely available to all, keep each person \& informed of events, allowing for a planned response that will take many variations. No one need issue an order to anyone. Those idealist truly committed to the cause of freedom will act when they feel the time is ripe, or will take their cue from others who precede them. ${ }^{\mathbf{2 8}}$

These ideas were in the $1990 \mathrm{~s}$ and $2000 \mathrm{~s}$ able to find response in the militant rightwing extremist spectrum in Western countries. A broad spectrum of violent actions committed by various actors (members of youth subcultures as racist skinheads, frustrated military veterans or idiosyncratic racists) required a reasonable strategic concept to improve the propagandist impact and efficiency of militant activities. "Leaderless resistance" was broadly accepted, at least as one of possible ways of the "fight against system".

Its spread was accompanied also by publications of other authors than Louis Beam. For example, in the novel "Hunter" written by Andrew Macdonald ${ }^{29}$ (pseudonym for William Pierce ${ }^{30}$ ), in the publication "Leaderless Resistance: Where There's a Will There's a Way "of British National Anarchist activist Troy Southgate ${ }^{\mathbf{3 1}}$ or in the guideline "The Field Manual" written by Max Hammer (pseudonym of the Norwegian neo-Nazi activist Erik Nielsen) for purposes of the transnational organization Blood \& Honour (he recommend the use of "leaderless resistance" only in some countries) ${ }^{32}$.

In the Czech Republic, "leaderless resistance" was propagated in the neo-Nazi spectrum in the second half of the $2000 \mathrm{~s}^{33}$. Mostly the neo-Nazi organizations National Resistance (Národní odpor - NO) and Autonomous Nationalists (AN) ${ }^{34}$ were inspired by them. They had the possibility to use also the Czech translation of the novel "Hunter" 35 . In 2015, the Czech translation of the original paper by Louis Beam was published in far

28 BEAM, Louis. 1992

29 MACDONALD, Andrew. The Hunter. 2. Hillsboro: National Vanguard Books, 1998. ISBN 9780937944097.

30 William Luther Pierce (1933-2002) was leader of the neo-Nazi organisation National Alliance.

31 MACKLIN, Graham D. Co-opting the counter culture: Troy Southgate and the National Revolutionary Faction. Patterns of Prejudice. 2005, 39(3), 301-326. DOI: 0.1080/00313220500198292. ISSN 14617331.

32 HAMMER, Max. The Field Manual. N: Blood \& Honour, 2000. ISBN N. Author's archive.

33 BEZPEČNOSTNÍ INFORMAČNÍ SLUŽBA. Čeští neonacisté se zviditelňují. Bezpečnostní informační služba [online]. Praha: Bezpečnostní informační služba, 2007 [cit. 2020-06-30]. Dostupné z: https:// www.bis.cz/aktuality/cesti-neonaciste-se-zviditelnuji-85429626.html

34 MAREŠ, Miroslav. Hrozba politického extremismu z hlediska ozbrojených sil České republiky. Vojenské rozhledy. 2009, 18(50)(2), 138-151. ISSN ISSN 1210-3292.

35 It was published by the publisher Kontingent Press. It included preface in which the publisher explained that the Czech edition was motivated by educational and anti-Racist aims. KONTINGENT PRESS. Předmluva. Lovec. Praha: Kontingent Press, 2008, s. 5-6. ISBN 978-80-254-3105-4. 
right circles ${ }^{36}$. The Czech scene transmitted the ideas of "leaderless resistance" to Slovak right-wing extremists ${ }^{37}$.

\section{REAL IMPACT OF “LEADERLESS RESISTANCE”}

However, despite the broad widespread of the idea of "leaderless resistance" its impact on real activities was for a long time limited. As an action inspired by this concept was mentioned mostly the Oklahoma city bombing on 19 April 1995. Two right-wing extremist perpetrators - Timothy McVeigh and Terry Nichols - attacked a federal building and killed 168 victims $^{38}$. According to expert Daniel Koehler, the German right-wing terrorist group National Socialist Underground (Nationalsozialitsicher Untergrund), which operated in 1999-2011, might have been influenced by Louis Beam's "leaderless resistance" ideas ${ }^{39}$.

But the use of "leaderless resistance" did not seem to be very efficient until the mid of the $2010 \mathrm{~s}$. A series of right-wing extremist lone-wolf attacks in Western countries in the second half of the second decade of the $21^{\text {st }}$ century (mostly in the year 2019 - New Zealand, USA, Germany) renewed academic debates about the concept. Some authors see in these attacks confirmation of the success of "leaderless resistance". ${ }^{40}$. During the time of the Corona-Crisis experts warn that the right-wing extremist scene in the USA uses the concept of "leaderless resistance" to accelerate violent protests against anti-pandemic restrictions and to support terrorist attacks (connected with racial-specific victims of the

36 LOUIS, Beam. Odpor bez vůdce. Délský potápěč [online]. Praha: Délský potápěč, 2015 [cit. 2020-06-30]. Dostupné z: https://deliandiver.org/2015/07/louis-beam-odpor-bez-vudce.html. The same publisher translated also a text critical towards "leaderless resistance" in which the author calls for a movement with a strong leader. MORGAN, John. Odpor s vůdcem aneb dilema dnešní pravice. Délský potápěč [online]. Praha: Délský potápěč, 2015 [cit. 2020-06-30]. Dostupné z: https://deliandiver.org/2015/03/odpor-svudcem-aneb-dilema-dnesni-pravice.html

37 JANÍČEK, Tomáš. Súčasné krajne pravicové násilie na Slovensku. Brno, 2015. Diplomová práce. Fakulta sociálních studií Masarykovy univerzity. Vedoucí práce Miroslav Mareš.

38 MARTIN, Gus. Understanding Terrorism. Challenges, Perspectives and Issues. 4. London: Sage, 2012. ISBN 978-1452205823.

39 KÖEHLER, Daniel. The German 'National Socialist Underground (NSU)' and Anglo-American Networks. The Internationalisation of Far-Right Terror. JACKSON, Paul a Anton SHEKHOVTSOV. The Post-War AngloAmerican Far Right: A Special Relationship of Hate. New York: Palgrave Macmillan, 2014, s. 122-141. ISBN 978-1-137-39621-1.

40 Leonard Weinberg stated: „The evident inability of the FBI and other law enforcement agencies to identify potential perpetrators, much less anticipate their attacks, provides support for Louis Beam's decades-old argument". WEINBERG, Leonard. Lone Wolf Attacks Prove Louis Beam Was Right About "Leaderless Resistance". Fair Observer [online]. Mountain View: Fair Observer, 2019 [cit. 2020-06-30]. Dostupné z: https://www.fairobserver.com/global-terrorism-news/ lone-wolf-attacks-louis-beam-leaderless-resistance-domestic-terrosrim-us-news-88710/ 
COVID-19 and with the federal character of measures) with the goal to attract more people to see its propagandist platforms (various chats in Telegram or Gab) ${ }^{\mathbf{4 1}}$.

Recent trend can confirm the impact of original Beam's ideas, however, it is not clear if all perpetrators really act with the intention that they are part of a resistance movement ${ }^{42}$. Declared inspiration by other lone wolves (Anders Breivik, Brenton Tarrant etc.) does not seem to be sufficient for labelling their attacks as "leaderless resistance". However, it is definitely a dangerous trend with a potential to mobilize further supporters.

The concept of "leaderless resistance" is broader than only lone-wolf terrorism ${ }^{\mathbf{4 3}}$. It should serve to a mass wave of subversive activities. Recent academic tendency to connect it only with lone-wolf terrorism is too narrow and it ignores the ideological and strategical dimension (among others production of leading ideas by strategic thinkers within the movement).

"Leaderless resistance" is not limited to the right-wing extremist scene. Similar concepts were developed also by other extremist streams. American expert Marc Sageman sees clear similarities between Beam's ideas and the main line of the publication "The Call to Global Islamic Resistance", written by Hakim (known as Abu Musab al-Suri or Mustapha Setmariam Nasr) from 2004. Sageman speaks in this context about "leaderless Jihad"44. Another expert, Paul Joosse, identified convergency between the structures of environmental extremists and "leaderless resistance"45. It is difficult to prove that Islamists or environmental extremists read Beam's paper, but due to many overlaps it is not excluded.

\section{6 “LEADERLESS RESISTANCE”, MILITARY SPHERE AND HYBRID THREATS}

If we turn back to the roots of Amos' and Beam's concepts of strong resistance movements which should be able to generate new leaders and more sophisticated forms of insurgent warfare, we do not see such success of "leaderless resistance" up to now. The

41 WALLNER, Claudia a Jessica WHITE. The Far-Right and Coronavirus: Extreme Voices Amplified by the Global Crisis. Royal United Services Institut [online]. London: Royal United Services Institut, 2020 [cit. 2020-06-30]. Dostupné z: https://rusi.org/commentary/ far-right-and-coronavirus-extreme-voices-amplified-global-crisis

42 KOEHLER, Daniel. Right-Wing Terrorism in the 21st Century: The 'National Socialist Underground' and the history of terror from the Far-Right in Germany. London: Routledge, 2017. ISBN 978-1138123281.

43 See the comprehensive strategic analysis (including propagandist aspects) in TOMASIEWICZ, Jarosław. Strategia oporu niekierowanego w wojnie asymetrycznej. Przeglqad Geopolityczny. 2009, 1(1), 161-190. ISSN 2080-8836. Dostupné také z: https://przeglad.org/wp-content/uploads/2015/01/ Tomasiewicz_Jaroslaw_PG_t.1.pdf.

44 SAGEMAN, Marc. Leaderless Jihad Terror Networks in the Twenty-First Century. Philadelphia: University of Pennsylvania Press, 2008. ISBN 9788170493532.

45 JOOSSE, Paul. Leaderless Resistance and Ideological Inclusion: The Case of the Earth Liberation Front. Terrorism and Political Violence. 2007, 19(3), 351-368. DOI: 10.1080/09546550701424042. ISSN 0954-6553. 
fact is that only acts of lone-wolf terrorists and small cells without capability to establish a strong and widespread militant movement remained. On the other hand, the security environment has changed in comparison with the Cold war and perception of warfare includes its new forms. In the new forms (or generations of warfare) the effectiveness of "leaderless resistance" can be improved.

Maintaining of the militant milieu and permanent mobilization of supporters (including the use of the internet) are basic conditions for building subversive capacities within the context of the $4^{\text {th }}$ generation warfare, which is based on asymmetric approaches. Expert George Michel even sees "leaderless resistance" as an adapting phenomenon to the Fifth-generation of warfare due to its growing connection with the use of modern technologies and transnationalisation. An unrestricted battlefield is typical of "leaderless resistance" as well as of the $5^{\text {th }} \mathrm{GW}^{46}$.

Despite the fact that military efficiency of "leaderless resistance" was relatively low up to now, we can find significant overlaps of its actors with the military sphere. The military background had several important authors or perpetrators related to "leaderless resistance". Louis Beam and Timothy McVeigh were both military veterans (Beam from the Vietnam war and Macveigh from the Gulf war). Frustrated soldiers or veterans can be due to their skills important members of small "phantom cells" or perpetrators of individual attacks.

In contrast, military staff can also be a target of attacks committed within the context of "leaderless resistance". They are perceived as part of the "system". Perpetrators can be other soldiers or people from non-military environment. It is important to mention that many contemporary individual terrorists consider themselves "soldiers" and they sometimes wear obscure uniforms during their actions or they link their acts to war conflicts ${ }^{47}$. It can cause also their interest to confront "real soldiers".

In broader context "leaderless resistance" can be utilized within the context of contemporary hybrid warfare. Spontaneous violent free network can cause chaos and it can facilitate operations of special forces and well directed paramilitary groups during the "hot phase" of the hybrid war. During the long-term hybrid campaigns, respectively within the context of political warfare ${ }^{48}$, stabile "leaderless resistance" movement can be used as a tool to weaken and discredit the enemy. Support of such movements by foreign intelligence returns us to the origins of Amoss' concept.

46 MICHAEL, George. Lone Wolf Terror and the Rise of Leaderless Resistance. Nashville: Vanderbilt University Press, 2011. ISBN 9780826518576.

47 HARTLEB, Florian. Lone Wolves: The New Terrorism of Right-Wing Single Actors. Cham: Springer, 2020. ISBN 9783030361525.

48 GALEOTTI, Mark. Russian political war: moving beyond the hybrid. London: Routledge, 2019. ISBN 978-113-8335-950. 


\section{COUNTERING “LEADERLESS RESISTANCE”}

"Leaderless resistance" is a flexible and adaptable phenomenon with a broad spectrum of varieties. Its countering poses a huge challenge due to its free and spontaneous character, including a propagandist threatening message which is connected with the spread of information about each act which can be affiliated with this concept ${ }^{49}$. Basic recommendation to counter "leaderless resistance" is to react to prevent it, after the outbreak to react to its fluid substance and to stop its spread and transformation into a strong efficient insurgent movement.

Countering "leaderless resistance" is a task for comprehensive security architecture which is able to react to the above mentioned varieties and development phases (from propaganda across lone-wolf and small-cell terrorism and diffused mass acts of subversion to transformation into more sophisticated insurgency). It requires innovative and autonomous approaches of individual institutions, however, also strong leadership. Leaderless counterterrorism and leaderless counterinsurgency are not welcomed, even if the enemy acts leaderlessly.

Regarding the specific features of "leaderless resistance", the following measures can be recommended:

1) Use of efficient counter-narratives. Success of "leaderless resistance" is based on commonly shared ideas. Their elimination is a task for the whole responsible political representation and society. Specific counter-narratives can be prepared by expert teams affiliated with governmental bodies;

2) Identification of lone-wolfs and small cells. Recently the crucial task is to improve methods to identify possible initiating persons and "foot soldiers" of leaderless resistance. As Florian Hartleb stated about perpetrators: "whenever a person states they are a "military detachment" in a combative mentality, openly expresses sympathy for using weapons, identifies himself with former actors of murderous deeds and murderous violent deeds as well as appears to be inspired by a missionary-like compulsion"50.

3) Efficient intelligence work in resistance milieu, which requires coordination of activities platforms for sharing information between criminal intelligence, foreign intelligence and military intelligence (due to the above mentioned overlaps with the military scene). Growing use of the internet and possible use of cyber-attacks by "leaderless resistance" should lead to involvement of institutions from cyber-security branch;

4) Law enforcement and justice treatment of "leaderless resistance" as a strategic concept. Juridical bodies should take into account that allegedly isolated acts are in fact part of a broader strategic concept;

49 Paul Joosse even describes „leaderless resistance“ as „a rhetorical construct, a meaning-conferring "ideology of effervescence" that lifts the spirits of both movement progenitors who advocate the strategy as well as incipient lone wolves who consider responding to their exhortations." JOOSSE, Paul. LeaderlesS Resistance and the Loneliness of Lone Wolves: Exploring the Rhetorical Dynamics of Lone Actor Violence. Terrorism and Political Violence. 2017, 29(1), 52-78. DOI: 10.1080/09546553.2014.987866. ISSN 0954-6553.

50 HARTLEB, Florian 2020. 
5) Appropriate military reactions in case of a serious outbreak of "leaderless resistance". In case of mass subversive activities of "phantom cells" with military equipment (including attacks at military deposits) to use efficient swarming tactics aimed to elimination of the most active cells and use of the concept of "area of responsibility" for control of insurgent territories ${ }^{51}$;

6) Paradoxically, the diffused and unorganized character of the resistance can be supported by counter-insurgent forces in the case when the threat of its transformation into a well-organized movement is growing. However, such approach must be temporarily limited and it should serve only to re-structuring and improvement of counter-insurgency.

\section{CONCLUSION}

If we examine the weak and strong points of the concept (which is sometimes called tactics and sometimes it is called strategy), we can see the mobilization potential as an "output-advantage." Many individuals can intensify their personal engagement in insurgent activities if they have the feeling that they are part of the mass "comprehensive strategy". An advantage for insurgents is also the fact that the holders of power are not fully able to identify all small cells and individuals. They can surprise with varieties of attacks. A weak government or occupation power can be pushed to capitulate only due to this mass scope of attacks. On the other side, the transition into efficient "war machine" is the biggest weakness in the case that the enemy is able to withstand uncoordinated attacks and step by step eliminate its insurgent enemies who are not able to organize a well organized and weaponized underground army for a "real battle". In future insurgencies the capability to maintain the function of the internet and electronic communication as such or to destroy modern communication technologies will be very important (and in such case to find a model for coordination of resistant activities without a leader).

"Leaderless resistance" is a vital subversive concept, despite the fact that its foundations were formulated in the early $1950 \mathrm{~s}$. Its original character as a tactics, which should be supported by US intelligence, was later transformed into broader strategic concepts used by extremists (including a part of the Czech extremist scene). The rise of new interest into "leaderless resistance" is caused due to a wave of lone-wolf terrorism in last years and topically also due to adaption of some extremists to the Corona-crisis. It can be misused also by drivers of various hybrid campaigns and within the context of political warfare. In the new situation "leaderless resistance" can be more dangerous than before. It requires also deep knowledge of the concept and efficient planning of counter-strategies in civilian, law-enforcement, intelligence and military branches.

51 FREUDENBERG, Dirk. Theorie des Irregulären: Partisanen, Guerillas und Terroristen im modernen Kleinkrieg. Wiesbaden: VS-Verlag für Sozialwissenschaften, 2008. ISBN 978-3531157375. 
This paper was written under the research project OPTIZ "Optimization of Intelligence Activities and Intelligence Institutions in the Changing Environment" (OPTIZ9070204510), funded by the Ministry of Defence of the Czech Republic ("Development of the Armed Forces of the Czech Republic" defence research programme).

Author: $\quad$ prof. Miroslav Mareš, PhD., born in 1974. He is the guarantor of security and strategic studies at the Department of Political Science of the Faculty of Social Studies of Masaryk University in Brno. He focuses on the research of extremism and terrorism in the Central Europe. He is a member of the European Expert Network on Terrorism Issues. He has worked with the OSCE and participated in the counter-extremism and the counter-terrorism activities of the European Union. He is an author or co-author of more than two hundred publications (among other with Astrid Bötticher they wrote the book Theorien, Extremism - Konzepte, Restoring, issued in 2012, in Munich).

How to cite: MAREŠ Miroslav. Leaderless resistance: Development, Countering and Research of Insurgent Concept. Vojenské rozhledy. 2020, 29 (3), 041-056. ISSN 1210-3292 (print), 2336-2995 (online). Available at: www.vojenskerozhledy.cz 